\title{
RISK MANAGEMENT OF WEST SEMARANG WATER SUPPLY PPP PROJECT: PUBLIC SECTOR PERSPECTIVE
}

\author{
Jati Utomo Dwi Hatmoko, Riza Susanti \\ Civil Engineering Department, Engineering Faculty, Diponegoro University, Indonesia \\ jati.hatmoko@ft.undip.ac.id, rizasusanti@ft.undip.ac.id
}

\begin{abstract}
While the need for water supply infrastructure development keeps increasing, many local governments of Indonesia are facing problems related to limited funding. This condition opens up an opportunity for private sector to invest in water supply infrastructure projects through Public Private Partnership (PPP) scheme. As this scheme is relatively new for many local governments in Indonesia, its complexity and typically long duration of the concession period may raise concerns of potential risks throughout the project life cycle. It is, therefore, very important for public sector as owner of the project to understand and to be able to manage risks properly throughout the concession period. The aim of this research is to evaluate risk management of West Semarang Water Supply PPP Project as perceived by public sector. The objectives are to identify, to analyze, and to allocate risks to the right parties. Qualitative and quantitative approaches have been used for the research method. Data were collected through focus group discussion involving 16 relevant officials of local government of Semarang, including its Regional Water Supply Company (PDAM). This research has identified a total of 66 risks as perceived by the public sector, which are then classified into 11 categories, e.g. political, operation, revenue, etc. The proportions of the level of risks are relatively balanced, as follows; low (37.88\%), moderate (28.79\%) and high (33.33\%). In terms of risk allocation, $46.97 \%$ of risks are allocated to the public sector, while $37.88 \%$ and $15.15 \%$ of the risks are allocated to the private sector and shared by both parties, respectively. The results of this research are valuable for the local government of Semarang and can be used as a guidance in managing risks of the PPP project throughout the concession period.
\end{abstract}

Keywords: risks, public private partnership, water supply, West Semarang.

\section{INTRODUCTION}

Regional Water Supply Company (PDAM) has been playing important roles in water supply services in many big cities in Indonesia, including in Semarang. The increasing demand of water supply has forced the local government to find ways to increase the level of service of PDAM and its coverage area. However, many local governments of Indonesia are facing problems related to limited funding.

The local government of Semarang City is currently seeking solutions to this problem by opening up an opportunity for private sector to participate in the provision of water supply through a Public Private Partnership scheme (PPP), also known as West Semarang Water Supply PPP Project. With the increasing demand of water supply on one hand, and the limited funding of local government, on the other hand, thus this option has been seen as an alternative solution in water supply provision in Semarang. It is expected that the level of service of the water supply can be improved significantly through this scheme.

PPP scheme is relatively new for many local governments in Indonesia, including Semarang. There are complex and long processes prior to a PPP project commences. The concession period of PPP typically last for long time, e.g. 20-30 years. These complexity and typically long duration of the concession period may raise concerns of potential risks throughout the project life cycle. These concerns are supported by Pangeran [1] who questioned the risk management capability of public sector organizations related to PPP Scheme Development for Water Supply in Indonesia. He found that from 20 organizations representing the local government agencies (Office of Public Works and BAPPEDA) and PDAM surveyed, most of their risk management capabilities are at the initial stage (level 2). This means that their risk management stances are typically supported by unstructured, ad-hoc and non-formal processes. It is, therefore, very important for public sector as owner of the project to understand and to be able to manage risks properly throughout the concession period. The aim of this research is to evaluate risk management of West Semarang Water Supply PPP Project as perceived by public sector. The objectives are to identify, to analyze, and to allocate risks to the right parties.

\section{LITERATURE REVIEW}

Evaluation of the implementation of PPP projects in water sector in developing countries has been reported based on four performance parameters, i.e. access (coverage expansion), quality of service, operational efficiency, and tariff levels [2]. It is estimated that since 1990 water PPP projects have granted access to piped water for more than 24 million people in developing countries. Quality of service has improved in some countries, in terms of water quality and continuity. Operational efficiency, measured by three main indicators, i.e. water losses, bill collection, and labour productivity, seems to be the area in which the private operators have positive contribution more consistently. Determining potential impact of tariff levels depends on the discrepancies between the initial tariff level from the costrecovery level and the efficiency level gained by the private operator, two of which move in opposite direction. Evaluation on tariffs shows increasing tariff levels overtime, but the underlying justifications are inaccessible.

National Development Planning Agency (BAPPENAS) reported challenges for PPP in water and sanitation sector in Indonesia [3], i.e. inadequate regulatory framework and cross-sector policy coordination on the provision of improved facilities for water supply and sanitation, decline in the quality and quantity of drinking water in urban areas, rapid growth of urban 
population which has been greater than the development of improved water and sanitation infrastructure, low community awareness on the importance of clean water use and sanitation, limited provision of improved drinking water by PDAMs and by privately owned water supply companies, limited capacity of subnational governments to ensure that improved drinking water and sanitation systems are in place or operating correctly, and inadequate investments in improved drinking water supply and sanitation systems, both for public and private sources. Despite of all these challenges, potential benefits of PPP in this sector still remains to be one best alternative for accelerating infrastructure development in Indonesia [4]. In addition, the private sector has also been keen to take part in financing, procuring and managing infrastructure projects [5]. Participation of private sector is expected to improve significantly the level service of the infrastructure, including in water supply sector.

Generally, risks are indeed inseparable throughout the life cycle of a construction project [6], including for PPP projects. World Bank noted that there are a number of potential risks associated with PPP projects [7], i.e. huge costs in preparation and on going of PPP projects, cost attached to debt, financing problems, politically or socially challenges, no unlimited risk bearing, limitation of scope of responsibility by private sector, government responsibility, expertise of the private sector, a clear legal and regulatory framework for achieving a sustainable solution, difficulty to identify all possible contingencies during project development that were not anticipated in the contract documents. All these risks have to be dealt with properly for the success of the project.

$\mathrm{Ng}$ and Loosemore [8] argue that benefits of a PPP project for public can be gained properly when project risks can be allocated appropriately between private and public sectors. In terms of risk allocation, a project with PPP scheme is different from a traditional project [9]. Technically, traditional project is typically a short-term transfer of risks between clients and contractors, while PPP is a more complex and long-term transfer of risks between the public and private sectors.
Risk allocation can be made properly only if both parties have common understanding of the risks [10]. Understanding a proper risk allocation will help the government to manage the project risks effectively [11].

\section{RESEARCH METHODS}

This research adopted qualitative and quantitative approaches to evaluate risk management as perceived by public sector. Data were collected through focus group discussion involving relevant project stakeholders from the public sector, consisting of key persons of local government officials, including the local Development Planning Agency (BAPPEDA) and PDAM of Semarang, as shown in Table 1. Examination on feasibility study and legal draft documents was also carried out to reinforce the understanding of the project.

Table 1. FGD participants

\begin{tabular}{llc}
\hline No & Subject & $\begin{array}{l}\text { Number of } \\
\text { participants }\end{array}$ \\
\hline 1. & Semarang local government & 8 \\
2. & BAPPEDA Semarang & 4 \\
3. & PDAM & 4 \\
\hline
\end{tabular}

Typical risk management framework has been used for this research, i.e. risk identification, risk analysis, and risk allocation. To measure the level of risks, the representatives of public sector were required to indicate the level of probability and the impact of risks using a five point rating scale. Table 2 shows a five point rating scale of probability that was set from 0.1 to 0.9 indicating a probability of occurrence from almost never to almost certain. While scale of the impact was set from 0.005 to 0.8 indicating level of impact of the risk from very low to very high. These rating scales are adopted from PMBOK 2008 [12]. The combination of probability and the impact of risks indicates risk levels, which then can be categorized into 3 groups, i.e. high risk, moderate risk and low risk, as shown in Table 2 below.

Table 2. Matrix of risk probability and risk impact [8]

\begin{tabular}{|c|c|c|c|c|c|}
\hline \multirow{2}{*}{ Probability } & \multicolumn{5}{|c|}{ Impact } \\
\cline { 2 - 6 } & $\begin{array}{c}0,005 \\
\text { very low }\end{array}$ & $\begin{array}{c}0,10 \\
\text { low }\end{array}$ & $\begin{array}{c}0,20 \\
\text { moderate }\end{array}$ & $\begin{array}{c}0,40 \\
\text { high }\end{array}$ & $\begin{array}{c}\text { v,80 } \\
\text { very high }\end{array}$ \\
\hline 0,90 & 0,05 & 0,09 & 0,18 & 0,36 & 0,72 \\
almost certain & Low & Moderate & High & High & High \\
\hline 0,70 & 0,04 & 0,07 & 0,14 & 0,28 & 0,56 \\
Likely & Low & Moderate & Moderate & High & High \\
\hline 0,50 & 0,03 & 0,05 & 0,10 & 0,20 & 0,40 \\
Possible & Low & Low & Moderate & High & High \\
\hline 0,30 & 0,02 & 0,03 & 0,06 & 0,12 & 0,24 \\
Unlikely & Low & Low & Moderate & Moderate & High \\
\hline 0,10 & 0,01 & 0,01 & 0,02 & 0,04 & 0,08 \\
almost never & Low & Low & Low & Low & Moderate \\
\hline
\end{tabular}

\section{RESULT AND DISCUSSION}

Construction Project Management 
This research has identified a total number of 66 risks as perceived by the public sector, which are then classified into 11 categories, i.e. location, design and construction, sponsor, financial, operation, revenue, connectivity, interface, political, force majeur and asset risk. This classification follows the risk allocation guideline for PPP project in Indonesia [13]. The analysis shows the proportions of the level of risks are relatively balanced, as follows; low (37.88\%), moderate (28.79\%) and high (33.33\%) (see Tables 3 and 4). It can be seen that high risk dominates the risks of revenue and operating. Revenue risk occurs when the project is unable to meet the demand or the agreed tariff or a combination of both. Risk factors included in the group of revenue risk are related to the risk of demand and tariffs. These risks can occur when the realization of the demand for the provision of services unexpectedly lower than forecast, due to factors such as changes of policy or regulation of the government. Besides the emergence of demand risk can also occur due to mistakes made by private parties both in the estimation of the volume of demand, or a decrease in the quality of service to customers. Risk rates occur if the service rate is lower than projected, this could be due to tariff adjustments on a periodic basis that is not done according to plan or level adjustable rates lower than the projection, as well as the estimation error rates or nonfulfillment of the standards required to request tariff adjustments.

High risk also dominates in risk operating category. Operating risk is the risk that the process for delivering the contracted services or an element of that process. It is occurs in operating phase in the life cycle of PPP projects. In general, the life cycle of the project on the project with the PPP scheme begins with the preconstruction, construction, commissioning, operation and transfer stage. After commissioning, the project will be in the operating phase, i.e. delivering water from source to the end users. Risks identified at this stage of the operation include raw water availability and service to customers. The complete risk analysis in West Semarang Water Supply PPP Project is shown in Table 3.

Table 3. Risk Analysis in West Semarang Water Supply PPP Project

\begin{tabular}{|c|c|c|c|c|c|c|c|c|}
\hline \multirow[t]{2}{*}{ No } & \multirow{2}{*}{$\begin{array}{l}\text { Type of } \\
\text { Risk }\end{array}$} & \multirow{2}{*}{ Code } & \multirow{2}{*}{ Risk Factor } & \multirow{2}{*}{$\begin{array}{l}\text { Risk } \\
\text { Level }\end{array}$} & \multirow{2}{*}{$\begin{array}{l}\text { Risk } \\
\text { Group } \\
\end{array}$} & \multicolumn{3}{|c|}{ Risk Allocation } \\
\hline & & & & & & Public & Private & Shared \\
\hline \multirow[t]{12}{*}{1.} & Location & R1 & $\begin{array}{l}\text { Land acquisition/ site } \\
\text { availability }\end{array}$ & 0,400 & High & $\mathrm{V}$ & - & - \\
\hline & & $\mathrm{R} 2$ & Cost of land acquisition & 0,080 & Moderate & $\mathrm{v}$ & - & - \\
\hline & & R3 & $\begin{array}{l}\text { Problem on land to be used for } \\
\text { transmission and distribution } \\
\text { networks }\end{array}$ & 0,560 & High & $\mathrm{V}$ & - & - \\
\hline & & $\mathrm{R} 4$ & $\begin{array}{l}\text { Landowners do not want to be } \\
\text { compensated }\end{array}$ & 0,240 & High & $\mathrm{v}$ & - & - \\
\hline & & R5 & $\begin{array}{l}\text { The ruler of the region does } \\
\text { not allow transmission and } \\
\text { distribution networks }\end{array}$ & 0,200 & High & $\mathrm{v}$ & - & - \\
\hline & & R6 & Budget financing delays & 0,120 & Moderate & $\mathrm{V}$ & - & - \\
\hline & & R7 & Land dispute & 0,010 & Low & $\mathrm{V}$ & - & - \\
\hline & & R8 & Unforseen site condition & 0,280 & High & - & $\mathrm{v}$ & - \\
\hline & & R9 & $\begin{array}{l}\text { Traffic disorders related to } \\
\text { transmission and distribution } \\
\text { networks }\end{array}$ & 0,140 & Moderate & $\mathrm{v}$ & - & - \\
\hline & & R10 & $\begin{array}{l}\text { Grabbing back land that has } \\
\text { been freed }\end{array}$ & 0,010 & Low & $\mathrm{V}$ & - & - \\
\hline & & R11 & $\begin{array}{l}\text { Location produce effluents } \\
\text { that pollute the environment }\end{array}$ & 0,120 & Moderate & - & - & $\mathrm{v}$ \\
\hline & & $\mathrm{R} 12$ & $\begin{array}{l}\text { Installation of transmission } \\
\text { and distribution networks that } \\
\text { causing dust on traffic }\end{array}$ & 0,140 & Moderate & - & - & $\mathrm{v}$ \\
\hline \multirow[t]{5}{*}{2.} & Design and & $\mathrm{R} 13$ & Output under prediction & 0,040 & Low & $\mathrm{V}$ & - & - \\
\hline & Construction & $\mathrm{R} 14$ & Redesign & 0,240 & High & - & $\mathrm{V}$ & - \\
\hline & & R15 & $\begin{array}{l}\text { Delays in the completion of } \\
\text { construction on the project } \\
\text { interfaces, delays in the } \\
\text { provision of water services to } \\
\text { the community }\end{array}$ & 0,080 & Moderate & - & $\mathrm{v}$ & - \\
\hline & & R16 & Cost overrun & 0,050 & Low & - & $\mathrm{v}$ & - \\
\hline & & R17 & $\begin{array}{l}\text { Cost overrun, delays in service } \\
\text { delivery }\end{array}$ & 0,030 & Low & - & $\mathrm{v}$ & - \\
\hline \multirow[t]{2}{*}{3.} & Sponsor & R18 & $\begin{array}{l}\text { Performance of sub- } \\
\text { contractors }\end{array}$ & 0,005 & Low & - & $\mathrm{v}$ & - \\
\hline & & R19 & Sponsorship & 0,005 & Low & - & $\mathrm{v}$ & - \\
\hline \multirow[t]{2}{*}{4.} & Financial & R20 & Financial close & 0,030 & Low & - & $\mathrm{v}$ & - \\
\hline & & R21 & Exchange rate & 0,030 & Low & - & $\mathrm{V}$ & - \\
\hline
\end{tabular}


The 2nd International Conference on Civil Engineering Research (ICCER) 2016

"Contribution of Civil Engineering toward Building Sustainable City"

\begin{tabular}{|c|c|c|c|c|c|c|c|c|}
\hline \multirow[t]{2}{*}{ No } & \multirow{2}{*}{$\begin{array}{l}\text { Type of } \\
\text { Risk }\end{array}$} & \multirow{2}{*}{ Code } & \multirow{2}{*}{ Risk Factor } & \multirow{2}{*}{$\begin{array}{l}\text { Risk } \\
\text { Level }\end{array}$} & \multirow{2}{*}{$\begin{array}{c}\text { Risk } \\
\text { Group }\end{array}$} & \multicolumn{3}{|c|}{ Risk Allocation } \\
\hline & & & & & & Public & Private & Shared \\
\hline \multirow{14}{*}{5} & \multirow{14}{*}{ Operation } & R22 & Inflation & 0,005 & Low & - & - & $\mathrm{V}$ \\
\hline & & R23 & Interest rate & 0,005 & Low & - & $\mathrm{v}$ & - \\
\hline & & $\mathrm{R} 24$ & $\begin{array}{l}\text { Availability of electricity, } \\
\text { access roads and drainage }\end{array}$ & 0,060 & Moderate & - & $\mathrm{v}$ & - \\
\hline & & $\mathrm{R} 25$ & $\begin{array}{l}\text { Poor quality of design, } \\
\text { construction, materials and } \\
\text { technology }\end{array}$ & 0,240 & High & - & $\mathrm{v}$ & - \\
\hline & & R26 & Strike & 0,400 & High & - & $\mathrm{v}$ & - \\
\hline & & $\mathrm{R} 27$ & $\begin{array}{l}\text { There are groups of opponents } \\
\text { of the policy / program in the } \\
\text { community. }\end{array}$ & 0,280 & High & - & - & $\mathrm{v}$ \\
\hline & & R28 & $\begin{array}{l}\text { Miscomunication between } \\
\text { consultant and contractor }\end{array}$ & 0,080 & Moderate & - & $\mathrm{v}$ & - \\
\hline & & R29 & $\begin{array}{l}\text { Monitoring failure by public } \\
\text { and private }\end{array}$ & 0,040 & Low & - & - & $\mathrm{v}$ \\
\hline & & R30 & $\begin{array}{l}\text { Cost estimating failure of } \\
\text { O\&M }\end{array}$ & 0,060 & Moderate & - & $\mathrm{v}$ & - \\
\hline & & R31 & Cost overrun & 0,030 & Low & - & $\mathrm{v}$ & - \\
\hline & & R32 & Delays in service delivery & 0,120 & Moderate & - & $\mathrm{v}$ & - \\
\hline & & R33 & $\begin{array}{l}\text { Availability of raw water } \\
\text { (continuity and quantity) }\end{array}$ & 0,400 & High & $\mathrm{v}$ & - & - \\
\hline & & R34 & Quality of raw water & 0,400 & High & $\mathrm{v}$ & - & - \\
\hline & & R35 & $\begin{array}{l}\text { Services to customer } \\
\text { interrupted }\end{array}$ & 0,080 & Moderate & & $\mathrm{v}$ & - \\
\hline \multirow[t]{6}{*}{6.} & \multirow[t]{6}{*}{ Revenue } & R36 & $\begin{array}{l}\text { Risk of the connection request, } \\
\text { Delay in the installation of } \\
\text { tertiary networks and SR }\end{array}$ & 0,560 & High & $\mathrm{v}$ & - & - \\
\hline & & R37 & The risk of failure tariffs & 0,280 & High & $\mathrm{v}$ & - & - \\
\hline & & R38 & $\begin{array}{l}\text { Risk of delays in the periodic } \\
\text { tariff increases }\end{array}$ & 0,280 & High & $\mathrm{v}$ & - & - \\
\hline & & R39 & $\begin{array}{l}\text { Revenue is lower than the rate } \\
\text { adjustment plan }\end{array}$ & 0,280 & High & $\mathrm{v}$ & - & - \\
\hline & & $\mathrm{R} 40$ & $\begin{array}{l}\text { Miscalculation estimated price } \\
\text { of water to the public, the } \\
\text { calculation of estimated error } \\
\text { rates to customers }\end{array}$ & 0,280 & High & $\mathrm{v}$ & - & - \\
\hline & & R41 & $\begin{array}{l}\text { Purchasing ability Semarang } \\
\text { Western society is not the } \\
\text { same as the city people of } \\
\text { Semarang }\end{array}$ & 0,280 & High & $\mathrm{v}$ & - & - \\
\hline \multirow[t]{7}{*}{7.} & \multirow[t]{7}{*}{ Connectivity } & $\mathrm{R} 42$ & $\begin{array}{l}\text { The risk of leakage / } \\
\text { contamination in the existing } \\
\text { network }\end{array}$ & 0,560 & High & $\mathrm{v}$ & - & - \\
\hline & & R43 & $\begin{array}{l}\text { Quality / specification } \\
\text { secondary distribution network } \\
\text { does not match the output } \\
\text { specification }\end{array}$ & 0,020 & Low & - & $\mathrm{v}$ & - \\
\hline & & R44 & $\begin{array}{l}\text { Failure secondary network } \\
\text { construction during the } \\
\text { operation, }\end{array}$ & 0,080 & Moderate & - & $\mathrm{V}$ & - \\
\hline & & R45 & $\begin{array}{l}\text { Tertiary network construction } \\
\text { delays }\end{array}$ & 0,080 & Moderate & $\mathrm{v}$ & - & - \\
\hline & & R46 & $\begin{array}{l}\text { Default of authorities to build } \\
\text { and maintain the necessary } \\
\text { network }\end{array}$ & 0,240 & High & $\mathrm{v}$ & - & - \\
\hline & & $\mathrm{R} 47$ & $\begin{array}{l}\text { Default of authorities not to } \\
\text { build the facility competitors }\end{array}$ & 0,010 & Low & $\mathrm{v}$ & - & - \\
\hline & & R48 & $\begin{array}{l}\text { Limitations management of } \\
\text { distribution networks built by } \\
\text { private }\end{array}$ & 0,010 & Low & $\mathrm{v}$ & - & - \\
\hline 8. & Interface & R49 & $\begin{array}{l}\text { Output is not absorbed in the } \\
\text { initial stages of operations in }\end{array}$ & 0,060 & Moderate & - & - & $\mathrm{v}$ \\
\hline
\end{tabular}


The 2nd International Conference on Civil Engineering Research (ICCER) 2016

"Contribution of Civil Engineering toward Building Sustainable City"

\begin{tabular}{|c|c|c|c|c|c|c|c|c|}
\hline \multirow[t]{2}{*}{ No } & \multirow{2}{*}{$\begin{array}{l}\text { Type of } \\
\text { Risk }\end{array}$} & \multirow{2}{*}{ Code } & \multirow{2}{*}{ Risk Factor } & \multirow{2}{*}{$\begin{array}{c}\text { Risk } \\
\text { Level }\end{array}$} & \multirow{2}{*}{$\begin{array}{c}\text { Risk } \\
\text { Group } \\
\end{array}$} & \multicolumn{3}{|c|}{ Risk Allocation } \\
\hline & & & & & & Public & Private & Shared \\
\hline \multirow{11}{*}{9.} & \multirow{11}{*}{ Political } & $\mathrm{R} 50$ & $\begin{array}{l}\text { accordance with contract } \\
\text { public production quality does } \\
\text { not comply with the agreement }\end{array}$ & 0,100 & Moderate & - & $\mathrm{v}$ & - \\
\hline & & R51 & Substantial rework & 0,030 & Low & $\mathrm{v}$ & - & - \\
\hline & & $\mathrm{R} 52$ & $\begin{array}{l}\text { The winning bidder came from } \\
\text { countries whose currencies } \\
\text { can not be converted into } \\
\text { rupiah }\end{array}$ & 0,010 & Low & - & $\mathrm{v}$ & - \\
\hline & & R53 & $\begin{array}{l}\text { Charges on infrastructure } \\
\text { located on national road }\end{array}$ & 0,720 & High & - & $\mathrm{v}$ & - \\
\hline & & $\mathrm{R} 54$ & Regulation & 0,140 & Moderate & $\mathrm{v}$ & - & - \\
\hline & & $\mathrm{R} 55$ & DED & 0,040 & Low & $\mathrm{v}$ & - & - \\
\hline & & R56 & $\begin{array}{l}\text { Permits (SIPA, location, } \\
\text { placement of piping) }\end{array}$ & 0,040 & Low & $\mathrm{v}$ & - & - \\
\hline & & R57 & Intake access & 0,280 & High & - & $\mathrm{v}$ & - \\
\hline & & R58 & Default of public & 0,040 & Low & - & $\mathrm{V}$ & - \\
\hline & & R59 & Default of Private & 0,200 & High & $\mathrm{v}$ & - & - \\
\hline & & R60 & $\begin{array}{l}\text { Substitution regional leaders } \\
\text { and Parliament }\end{array}$ & 0,040 & Low & $\mathrm{v}$ & - & - \\
\hline \multirow[t]{4}{*}{10.} & \multirow{4}{*}{$\begin{array}{l}\text { Force } \\
\text { Majeur }\end{array}$} & R61 & Natural disaster & 0,120 & Moderate & - & - & $\mathrm{v}$ \\
\hline & & R62 & $\begin{array}{l}\text { Upheavals result in overall } \\
\text { government changed }\end{array}$ & 0,040 & Low & - & - & $\mathrm{v}$ \\
\hline & & R63 & Climate change & 0,120 & Moderate & - & - & $\mathrm{v}$ \\
\hline & & R64 & $\begin{array}{l}\text { Reservoir conditions are } \\
\text { impaired (sedimentation), } \\
\text { resulting in raw water supply } \\
\text { is not in accordance with the } \\
\text { target }\end{array}$ & 0,120 & Moderate & - & - & $\mathrm{v}$ \\
\hline \multirow[t]{2}{*}{11.} & \multirow[t]{2}{*}{ Asset } & R65 & $\begin{array}{l}\text { Condition of asset after the } \\
\text { completion of the agreement }\end{array}$ & 0,005 & Low & $\mathrm{v}$ & - & - \\
\hline & & R66 & $\begin{array}{l}\text { The risk of asset ownership } \\
\text { status after transfer }\end{array}$ & 0,005 & Low & $\mathrm{v}$ & - & - \\
\hline
\end{tabular}

Table 4. Risk Probability and Impact Matrix of West Semarang Water Supply PPP Project

\begin{tabular}{|c|c|c|c|c|c|}
\hline \multirow[b]{2}{*}{ Probability } & \multicolumn{5}{|c|}{ Impact } \\
\hline & $\begin{array}{c}0,005 \\
\text { very low }\end{array}$ & $\begin{array}{l}0,10 \\
\text { low }\end{array}$ & $\begin{array}{c}0,20 \\
\text { moderate }\end{array}$ & $\begin{array}{l}0,40 \\
\text { high }\end{array}$ & $\begin{array}{c}0,80 \\
\text { very high }\end{array}$ \\
\hline $\begin{array}{c}0,90 \\
\text { almost } \\
\text { certain }\end{array}$ & Low & Moderate & High & High & $\begin{array}{l}\text { High } \\
\text { (R53) }\end{array}$ \\
\hline $\begin{array}{l}0,70 \\
\text { likely }\end{array}$ & Low & Moderate & $\begin{array}{c}\text { Moderate } \\
(R 9, R 12, R 54)\end{array}$ & $\begin{array}{c}\text { High } \\
(R 8, R 37, R 38, \\
R 39, R 40, R 41, \\
\text { R57) }\end{array}$ & $\begin{array}{c}\text { High } \\
(R 3, R 36, R 42)\end{array}$ \\
\hline $\begin{array}{c}0,50 \\
\text { possible }\end{array}$ & Low & $\begin{array}{l}\text { Low } \\
(R 16)\end{array}$ & $\begin{array}{l}\text { Moderate } \\
\text { (R50) }\end{array}$ & $\begin{array}{c}\text { High } \\
(R 5, R 59)\end{array}$ & $\begin{array}{c}\text { High } \\
(R 1, R 26, R 27)\end{array}$ \\
\hline $\begin{array}{c}0,30 \\
\text { unlikely }\end{array}$ & Low & $\begin{array}{c}\text { Low } \\
(R 17, R 20, \\
R 21, R 31, \\
R 51)\end{array}$ & $\begin{array}{c}\text { Moderate } \\
\text { (R24, R30, } \\
\text { R49) }\end{array}$ & $\begin{array}{c}\text { Moderate } \\
(R 6, R 11, R 34, \\
R 61, R 63, R 64)\end{array}$ & $\begin{array}{c}\text { High } \\
\text { (R4, } R 14, R 25, \\
\text { R46) }\end{array}$ \\
\hline $\begin{array}{l}0,10 \\
\text { almost } \\
\text { never }\end{array}$ & $\begin{array}{c}\text { Low } \\
(R 18, R 19, \\
R 22, R 23, \\
R 65, R 66)\end{array}$ & $\begin{array}{c}\text { Low } \\
(R 7, R 10, \\
R 47, R 48, \\
\text { R52) }\end{array}$ & $\begin{array}{l}\text { Low } \\
(R 43)\end{array}$ & $\begin{array}{c}\text { Low } \\
\text { (R13, R29, R55, } \\
R 56, R 58, R 60, \\
R 62)\end{array}$ & $\begin{array}{c}\text { Moderate } \\
\text { (R2, R15, R28, } \\
\text { R35, R44, } \\
\text { R45) }\end{array}$ \\
\hline
\end{tabular}

It can be seen in Table 3 that in general the risks related to the problem of land acquisition or site availability have higher probability and impact values compared to other risks. Land acquisition or site availability is an important issue for project because it has a significant impact on the realization of projects that may 
lead to the emergence of other risks. Summary risk analysis in West Semarang water supply PPP project is presented in Table 4.

The principle of risk allocation is to transfer risks to the best party which is which is capable to bear the risks effectivelly with minimum costs [11]. Table 3 shows that $46.97 \%$ of risks are allocated to the public sector, while $37.88 \%$ and $15.15 \%$ of the risks are allocated to the private sector, and shared by both parties. The risks allocated to the public sector include location, revenue, and political risks. The private sector in general bears the risks of design and construction, sponsor, financial and operation. The risk to be shared by both parties is force majeure.

Risks related to the problems of land acquisition or site availability is an important issue for public as it can lead to project delays, hence these risks are considered best borne by the public (local government of Semarang). Risk factors in group of revenue risks in general is related to the risks of tariff uncertainty which are considered best allocated to public (government). Political risks, associated with government regulatory issues, are also allocated to the public. The existence of regional regulations are intended as guidelines and provide a legal basis in the preparation and implementation of the project, as well as providing legal certainty to the sustainability of the project. In practice, public sector (government) has full control among the location risk, revenue risk and political risk.

Risks allocated to the private sector are mainly related to the project design and construction, sponsor, financial and operation. Risk factors in design and construction include risks of redesign, delays of project completion, cost overrun. Other risk factors in sponsor and financial include performance of subcontractors, sponshorship, financial close, exchange rate and interest rate. Risk factors in operation are dominant as they are in full controll of private sector, include availability of electricity, access roads and drainage, poor quality of design, construction, materials and technology, cost estimating failure of operation and maintenance, etc.

Risks shared by both parties are mainly force majeure risks. Force majeure risks are force majeure events which are completely outside the control of both parties, both natural and human-caused disasters that will result in a delay or default on the part of the private sector in the implementation of compliance obligations [13]. The risk factors of force majeure include natural disaster, upheavals which result in overall government changed, climate change, reservoir conditions which are impaired by sedimentation, resulting in raw water supply is not in accordance with the target. As the public and private sectors may not be able to deal with force majeure risks alone, therefore sharing the risks would be the best option. This is also the case in the UK, where risks considered as force majeur events are also allocated to both parties [14].

\section{CONCLUSION}

The research has identified a total number of 66 risks of West Semarang Water Supply PPP Project as perceived by the public sector, which are then classified into 11 categories, e.g. political, operation, revenue, etc. The proportions of the level of risks are relatively balanced, as follows; low (37.88\%), moderate (28.79\%) and high (33.33\%). In terms of risk allocation, $46.97 \%$ of risks are allocated to the public sector, while $37.88 \%$ and $15.15 \%$ of the risks are allocated to the private sector and shared by both parties. The public sector should retain risks related to location risk, revenue risk and political risk. Risks related to the project design and construction, financial risks and operating risks are best borne by private sector, while force majeure risk should be shared by both parties. The results of this research are valuable for the local government of Semarang and can be used as a guidance in managing risks of the PPP project throughout the concession period.

This research has analyzed risk management of West Semarang Water Supply PPP Project as perceived by public sector. The success of handling these risks during the concession period, however, will also be dependent on the public sector internal capacity. Therefore, it is important for further research to assess the capacity of risk management of the local Government of Semarang in relation to this project. By assessing its capacity of risk management, it is expected that the potential risks that may arise during the concession period may be managed in a proper, systemic and more sustainable ways.

\section{AKNOWLEDGEMENTS}

The authors wish to acknowledge the contributions of Indonesia Infrastructure Guarantee Fund (IIGF), local government of Semarang and industry practitioners who have supported and contributed their valuable input in Focus Group Discussion for this research.

\section{REFERENCES}

[1] Pangeran M.H, Pribadi K.S., Wirahadikusumah R.D., and Notodarmojo S, "Assessing Risk Management Capability of Public Sector Organizations related to PPP Scheme Development for Water Supply in Indonesia”, Civil Engineering Dimension, Vol. 14, No. 1, 26-35 ISSN 1410-9530 print / ISSN 1979-570X online, March, 2012

[2] Marin P., "Public-private partnerships for urban water utilities: a review of experiences in developing countries”, World Bank Publications Vol. 8, 2009

[3] BAPPENAS, "Report on Achievement of Millennium Development Goals", BAPPENAS Publications, 2010

[4] The Canadian Council for Public-Private Partnerships, "Why Choose PPP's?" available at http://www.pppcouncil.ca. accessed 20 December 2015

[5] Cottle, G., Risks associated with public private partnership arrangements and private finance initiatives. Through the Looking Glass, 2003

[6] Rahman M., Kumaraswamy M.M, "Risk management trends in the construction industry: moving towards joint risk management”, Journal Engineering, Construction and Architectural Management 2002(9) pp. 131-151, 2002

[7] World Bank, "Potential Risks Of Public Private Partnerships”, available at http://ppp.worldbank.org/, accessed 16 December 2015 
The 2nd International Conference on Civil Engineering Research (ICCER) 2016

"Contribution of Civil Engineering toward Building Sustainable City"

[8] Ng, A. and Loosemore, M., "Risk allocation in the private provision of public infrastructure", International Journal of Project Management, Vol 25 No. 1, pp. 66-76, 2007

[9] Milner M, "Eurotunnel car traffic declines", The Guardian, pp. 14, March, 2004

[10] Andi, "The importance and allocation of risks in Indonesian construction projects", Construction Management and Economics Vol. 24, pp. 69-80, Januari, 2006

[11] Wibowo A. and Mohamed S., "Perceived Risk Allocation in Public-Private-Partnered (PPP) Water Supply Projects in Indonesia”, Construction in Developing Countries, pp.349, 2008

[12] Project Management Institute, "A Guide to the Project Management Body of Knowledge (PMBOK) 4th edition”, Project Management Institute Inc: Pensylvania, 2008

[13] IIGF, "Risk Allocation Guideline Public Private Partnership Edition: March 2015”, IIGF Publication, 2015

[14] Bing L., Akintoye A., Edwards P.J. and Hardcastle, C., " The allocation of risk in PPP/PFI construction projects in the UK”, International Journal of project management, Vol. 23 No.1 , pp.25-35, 2005 